\title{
ACTH is a potent regulator of gene expression in human adrenal cells
}

\author{
Yewei Xing, C Richard Parker ${ }^{1}$, Michael Edwards and William E Rainey \\ Departments of Physiology and Surgery, Medical College of Georgia, 1120 15th Street, Augusta, Georgia 30912, USA \\ 'Department of Obstetrics and Gynecology, University of Alabama at Birmingham, Birmingham, Alabama 35233, USA \\ (Correspondence should be addressed to W E Rainey; Email: wrainey@mcg.edu)
}

\begin{abstract}
The adrenal glands are the primary source of minerocorticoids, glucocorticoids, and the so-called adrenal androgens. Under physiological conditions, cortisol and adrenal androgen synthesis are controlled primarily by ACTH. Although it has been established that ACTH can stimulate steroidogenesis, the effects of ACTH on overall gene expression in human adrenal cells have not been established. In this study, we defined the effects of chronic ACTH treatment on global gene expression in primary cultures of both adult adrenal (AA) and fetal adrenal (FA) cells. Microarray analysis indicated that $48 \mathrm{~h}$ of ACTH treatment caused 30 AA genes and 84 FA genes to increase by greater than fourfold, with 20 genes common in both cell cultures. Among these genes were six encoding enzymes involved in steroid biosynthesis, the ACTH receptor and its accessory protein, melanocortin 2 receptor accessory protein (ACTH receptor accessory protein). Real-time quantitative PCR confirmed the eight most upregulated and one downregulated common genes between two cell types. These data provide a group of ACTH-regulated genes including many that have not been previously studied with regard to adrenal function. These genes represent candidates for regulation of adrenal differentiation and steroid hormone biosynthesis.
\end{abstract}

Journal of Molecular Endocrinology (2010) 45, 59-68

\section{Introduction}

ACTH is a 39 amino acid polypeptide predominantly synthesized in and secreted from the anterior lobe of the pituitary gland. The synthesis and secretion of ACTH are tightly controlled by the hypothalamicpituitary-adrenal axis. Under stress conditions, the paraventricular nucleus of the hypothalamus secretes vasopressin and CRH. These two peptides regulate the anterior lobe of the pituitary gland and stimulate the secretion of ACTH. ACTH subsequently induces adrenal cortex expansion and corticosteroid production (mainly cortisol in humans). Once synthesized, cortisol in turn acts on the hypothalamus and pituitary (to suppress CRH and ACTH production) causing a negative feedback cycle. In the adrenal glands, ACTH acts by binding to specific cell surface ACTH receptors (melanocortin 2 receptor (MC2R)). MC2R is a seven membrane-spanning G-protein-coupled receptor that is primarily expressed in adrenocortical cells. Upon ligand binding, the receptor undergoes conformational changes that stimulate adenylyl cyclase, leading to an increase in intracellular cAMP and subsequent activation of protein kinase A (PKA).

Although previous studies have identified some ACTH-responsive genes that are involved with the steroidogenic and growth-related effects of ACTH (Neri et al. 1991, Markowska et al. 1993, Cecim et al. 1996,
Gaillard et al. 2000, Le Roy et al. 2000, Simmonds et al. 2001, Banerjee et al. 2008), there is a lack of knowledge regarding the global actions of ACTH on gene expression. Given the critical role of ACTH in adrenal development, steroidogenesis, and disease, it is appropriate to further define the detailed effects of ACTH on human adrenal cell gene expression. In this study, we used oligonucleotide microarray analysis to define the effects of ACTH on gene expression in primary cultures of human adrenocortical cells. The study has defined a series of ACTH-responsive genes that greatly expands our understanding of ACTH action in humans.

\section{Materials and methods}

\section{Tissue collection}

Human adult adrenal (AA) glands were obtained from cadaveric kidney donors transplanted at the Medical College of Georgia (Augusta, GA, USA) with the family's informed consent obtained by LifeLink of Georgia. Human fetal adrenal (FA) glands (14-19 weeks of gestation) were obtained from pathological examination following elective pregnancy terminations from Advanced Bioscience Resources Inc. (Alameda, CA, USA) with informed consent. The use of these tissues was approved by the Institutional Review Board 
of Medical College of Georgia and the University of Alabama at Birmingham (Birmingham, AL, USA).

\section{Cell culture and treatment}

Adult adrenocortical cells were isolated with collagenase-dispase digestion as described previously (Bassett et al. 2004). The AAs were minced and dissociated into single cell suspension by repeated exposure of the tissue fragments to DMEM/F12 medium (Invitrogen) containing $1 \mathrm{mg} / \mathrm{ml}$ of collagenase-dispase and $0.25 \mathrm{mg} / \mathrm{ml}$ of DNase-1 (F Hoffmann-La Roche Ltd). Digestion and mechanical dispersion were carried out four times for $1 \mathrm{~h}$ each at $37^{\circ} \mathrm{C}$. Cells were collected between each digestion, and combined before aliquots of AA cells were frozen (2000 000 cells per vial) and stored at $-150{ }^{\circ} \mathrm{C}$.

FAs were minced and dissociated into single cell suspensions by repeated exposure of the tissue fragments to $0.4 \mathrm{mg} / \mathrm{ml}$ collagenase (Sigma) in PBS enriched with $10 \%$ BSA (Sigma) at $37^{\circ} \mathrm{C}$ for $15-30 \mathrm{~min}$. After separation of the cells from the collagenase mixture by centrifugation, the cell pellets were suspended in culture medium (McCoy's 5A medium (Gibco) that contained $5 \%$ fetal bovine serum (Hyclone, Logan, UT, USA) and antibiotics/antimycotics (Gibco)). Cells were initially cultured in Falcon 75cc flasks (Becton Dickenson \& Co., Lincoln Park, NJ, USA) for 2-3 days at $37^{\circ} \mathrm{C}$ in a humidified atmosphere $\left(95 \%\right.$ air and $\left.5 \% \mathrm{CO}_{2}\right)$ to ensure viability and lack of infection prior to experimental use.

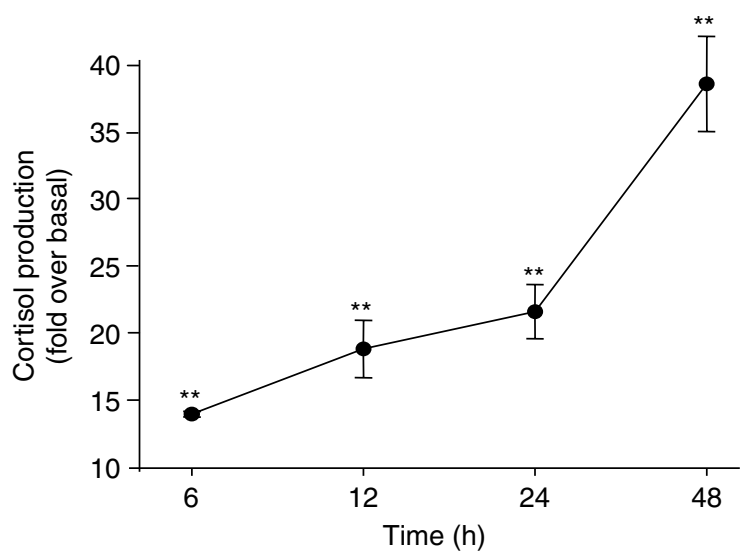

Figure 1 Time-dependent effects of ACTH on cortisol production in human AA cells. Primary human AA cells were prepared as described under Materials and methods, and plated at the density of 200000 cells per well in 24-well dishes. Cells were treated with or without ACTH (10 nM) for the indicated times, and cortisol was quantified in the medium using EIA. Cortisol data were normalized to protein per well and expressed as the fold change over basal condition (untreated cells) for each time point. Results represent the mean \pm S.E.M. of data from at least three independent experiments. Three wells were analyzed for individual treatment in each experiment. Statistics were calculated using one-way ANOVA followed by Dunnett's test, comparing with baseline. ${ }^{\star \star} P<0.01$.
For experiments, AA or FA cells were subcultured and plated at a density of 200000 cells/well in 24-well dishes and allowed to grow for 5 days in complete growth medium (10\% cosmic calf serum (Hyclone) and $1 \%$ antibiotic for AA cells, and $10 \%$ cosmic calf serum, $1 \%$ ITS plus (BD Diagnostic Systems, Sparks, MD, USA), and $1 \%$ antibiotic for FA cells; Rehman et al. 2007). The day before treatment, the cells were changed to experimental medium $(0 \cdot 1 \%$ cosmic calf serum and $1 \%$ antibiotics for AA cells, and $1 \%$ cosmic calf serum, $1 \%$ ITS plus, and $1 \%$ antibiotic for FA cells) for overnight incubation followed by 48-h treatment with or without ACTH (10 nM; Organon, Bedford, OH, USA). The cells were lysed for RNA isolation, and the media were collected for steroid assays as described below.

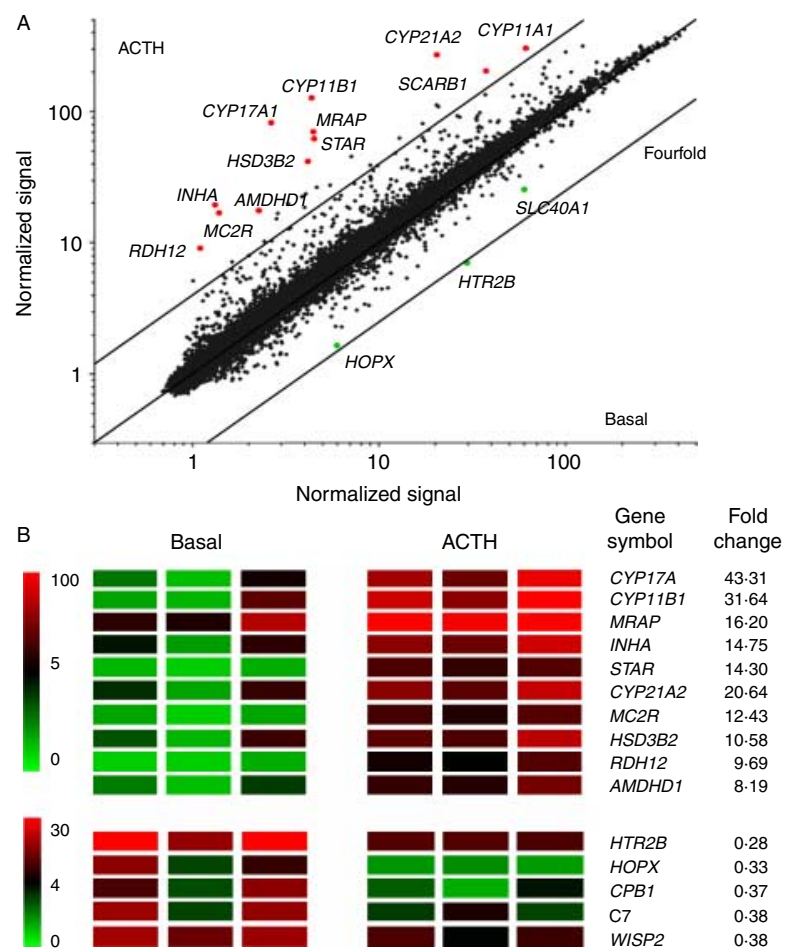

Figure 2 Microarray analysis of ACTH effects on AA cell gene expression. (A) Scatter plot comparing gene expression between basal and ACTH-treated AA samples. Total RNA from three sets of primary AA cell samples treated with or without ACTH was used for six oligonucleotide microarrays, and the data were combined to form this plot. The graph represents 37846 transcripts that were found to have a signal above background level in at least one tissue sample. The transcripts with the highest variation between the basal and ACTH treatments are labeled. (B) Heatmap of the fifteen most differentially expressed transcripts between three basal and three ACTH-treated samples. The top ten upregulated and top five downregulated genes are given here. Colors represent the expression level from the median of all the samples for each probe set. Results represent data from three experiments using cells isolated from three independent donor adrenal glands. Full colour version of this figure available via http://dx.doi.org/ 10.1677/JME-10-0006. 


\section{RNA isolation}

Total RNA was extracted from human adrenal cells using the RNeasy mini kit from Qiagen following the manufacturer's protocol, and the quantity of RNA was checked spectroscopically using a Nanodrop spectrophotometer (NanoDrop Technologies, Wilmington, DE, USA). Deoxyribonuclease I (Ambion Inc., Austin, TX, USA)-treated total RNA $(2 \mu \mathrm{g})$ was reverse transcribed using the High Capacity cDNA Archive kit (Applied Biosystems, Foster City, CA, USA) and stored at $-80^{\circ} \mathrm{C}$.

\section{Microarray analysis}

Total adrenal cell RNA from basal and ACTH-treated cells was used on genomic expression arrays performed by the Microarray Core Facility at the Medical College of Georgia. Briefly, FA RNA was hybridized to Illumina HumanRef-8 (gene targets 24526 ), and AA RNA was hybridized to HumanHT-12 (gene targets 48 804) Expression BeadChips (Illumina, San Diego, CA, USA). Results were analyzed using GeneSpring GX 7.3.1 software (Silicon Genetics, Redwood City, CA, USA) and normalized to the 50 th percentile of all signal values.

\section{Quantitative real-time RT-PCR}

Inhibin, alpha (INHA), HOP homeobox (HOPX), and MC2R accessory protein (MRAP) primers were obtained from Qiagen, and the mRNA levels were detected using SYBR Green PCR master mix
(Applied Biosystems). CYP11B1, HSD3B2, CYP17, CYP21, and steroidogenic acute regulatory protein (STAR) primer/probe mix was prepared following the sequence published before (Pezzi et al. 2003). The Taqman gene expression assay for MC2R was purchased from Applied Biosystems. qPCRs were performed using the ABI Prism 7000 Sequence Detection System (Applied Biosystems) in a total volume of $20 \mu \mathrm{l}$ reaction mixture following the reaction parameters recommended by the manufacturer. Relative quantification of mRNA levels between treated/untreated groups was determined using the comparative $C_{\mathrm{t}}$ value as described previously (Ye et al. 2007) with $18 \mathrm{~S}$ rRNA used for normalization.

\section{Protein extraction and protein assay}

Cells were lysed in $100 \mu \mathrm{l}$ of Mammalian Protein Extraction Reagent (Pierce Chemical Co., Rockford, IL, USA). The protein content of samples was then determined by the bicinchoninic acid protein assay following the MicroBCA protocol (Pierce Chemical Co).

\section{Steroid immunoassay}

Steroid determinations were done using EIA kits for cortisol (Alpco Diagnostics, Salem, NH, USA) and dehydroepiandrosterone sulfate (DHEA-S; Diagnostic System Laboratories, Webster, TX, USA). The assays were conducted following the manufacturer recommendations, except that standard curves were prepared in the experimental cell culture medium.

Table 1 Transcripts most regulated by ACTH treatment in adult adrenal (AA) cells. Primary human AA cell culture was treated with/without ACTH (10 nM) for $48 \mathrm{~h}$, and RNA was isolated for microarray analysis. Ten genes most upregulated and five genes most downregulated by ACTH treatment in human AA are shown. The gene symbol for each transcript is given in the first column, followed by the fold change between basal and ACTH (mean fold change of three independent experiment \pm S.E.M.) treatments and $P$ value. Results represent data from three experiments using cells isolated from three independent donor adrenal glands

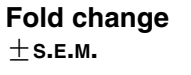

Gene symbol

$\begin{array}{llll}\text { CYP11B1 } & 43.31 \pm 19.95 & 0.168 & \text { NM_001026213.1 } \\ \text { CYP17A1 } & 31.64 \pm 1.12 & 0.001 & \text { NM_000102.3 } \\ \text { CYP21A2 } & 20.64 \pm 9.31 & 0.169 & \text { NM_000500.5 } \\ \text { MRAP } & 16.20 \pm 2.49 & 0.026 & \text { NM_178817.3 } \\ \text { INHA } & 14.74 \pm 0.52 & 0.001 & \text { NM_002191.2 } \\ \text { STAR } & 14.30 \pm 2.36 & 0.030 & \text { NM_001007243.1 } \\ \text { MC2R } & 12.42 \pm 1.62 & 0.020 & \text { NM_000529.2 } \\ \text { HSD3B2 } & 10.58 \pm 2.54 & 0.064 & \text { NM_000198.2 } \\ \text { RDH12 } & 9.69 \pm 4.03 & 0.164 & \text { NM_152443.1 } \\ \text { AMDHD1 } & 8.19 \pm 1.74 & 0.054 & \text { NM_152435.1 } \\ \text { HTR2B } & 0.28 \pm 0.11 & 0.0221 & \text { NM_000867.3 } \\ \text { HOPX } & 0.33 \pm 0.14 & 0.0431 & \text { NM_032495.4 } \\ \text { CPB1 } & 0.37 \pm 0.06 & 0.0084 & \text { NM_001871.2 } \\ \text { C7 } & 0.38 \pm 0.01 & 0.0001 & \text { NM_000587.2 } \\ \text { WISP2 } & 0.38 \pm 0.08 & 0.0166 & \text { NM_003881.2 }\end{array}$

GenBank accession

number Gene name

$P$ value was calculated using paired $t$-test comparing the fold changes with/without ACTH treatment. 
Results were normalized to protein per tissue culture well, and were shown as fold changes compared to basal treatment.

\section{Statistical analysis}

Results are given as mean \pm s.E.M. Individual experiments were repeated at least three times, using cells isolated from separate adrenal glands. One-way ANOVA or paired $t$-test was performed using GraphPad Prism 3.0 (GraphPad Software, Inc., San Diego, CA, USA).

\section{Results}

\section{ACTH stimulates cortisol production in AA cells}

As shown in Fig. 1, treatment of AA cells with ACTH $(10 \mathrm{nM})$ resulted in a significant elevation of cortisol biosynthesis. Media content of cortisol increased following ACTH treatment in a time-dependent manner. ACTH caused a significant increase in medium cortisol within $6 \mathrm{~h}$, and by $48 \mathrm{~h}$, ACTH increased cortisol by over 30 -fold above that seen in untreated cells.

\section{Microarray data of AA 48-h treatment with ACTH}

To determine the global gene changes caused by ACTH treatment in AA cells, microarray analysis was performed comparing basal and ACTH

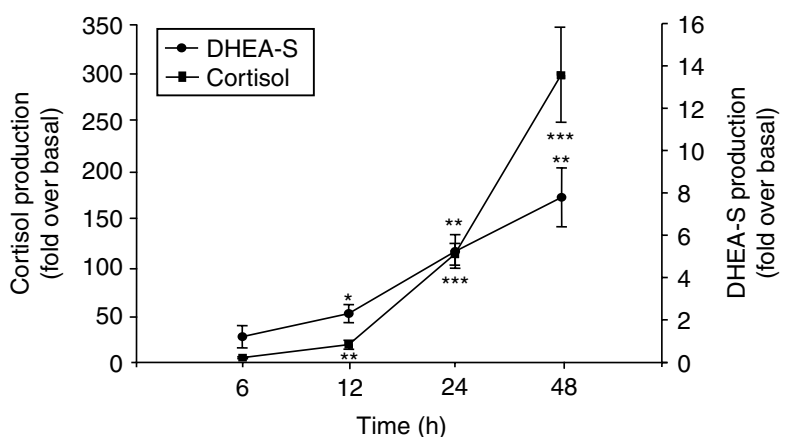

Figure 3 Time-dependent effects of ACTH on cortisol and DHEA-S production in FA primary cultures. Primary human FA cells were prepared as described under Materials and methods, and plated at a density of 200000 cells per well in 24-well dishes. The day before experiments, cells were changed to $1 \%$ low serum medium overnight. Cells were treated with ACTH (10 nM) for the indicated times followed by quantification of medium cortisol and DHEA-S using EIA kits. Steroid data were normalized to protein per well and expressed as the fold change over basal conditions (untreated cells) for each time point. Results represent the mean \pm S.E.M. of data from at least three independent experiments. Three wells were analyzed for individual treatment in each experiment. Statistics were calculated using one-way ANOVA followed by Dunnett's test, comparing with baseline. ${ }^{*} P<0.05$; ${ }^{\star *} P<0.01 ;{ }^{* \star} P<0.001$.
(10 nM, $48 \mathrm{~h}$ )-treated samples (Fig. 2A). Cells were isolated from three independent donor adrenal glands and used for independent experiments. Six microarrays were run with three sets of basal and ACTH-treated samples. Among the 37846 genes shown in the scatter plot, 30 genes were upregulated by ACTH over fourfold, while only one gene (serotonin receptor 2B, $H T R 2 B$ ) was downregulated for more than fourfold. The top upregulated and downregulated genes are shown in the microarray heatmap (Fig. 2B) and listed in Table 1.

As shown in Fig. 2 and Table 1, all steroidogenic enzymes involved in adrenal cortisol production were

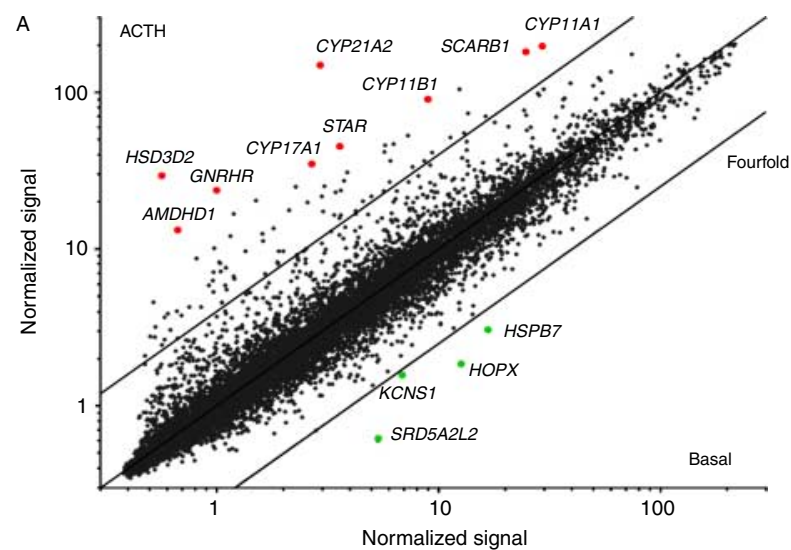

B

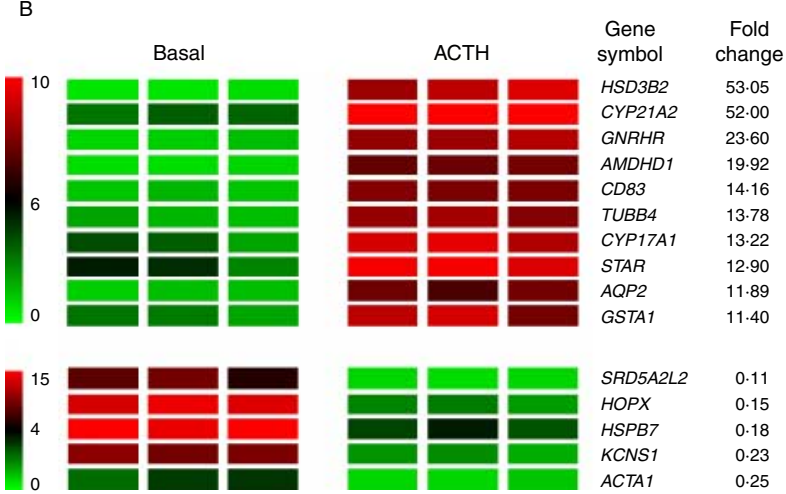

Figure 4 Microarray analysis of ACTH effects on FA cell gene expression. (A) Scatter plot comparing gene expression between basal and ACTH-treated samples in FA cells. Total RNA from three sets of primary adrenal samples treated with or without ACTH was used for oligonucleotide microarray analysis, and the data were combined. The graph represents 18391 transcripts that were found to have a signal above background level in at least one cell sample. The transcripts with the highest variation between basal and ACTH treatments are labeled. Results represent data from three experiments using cells isolated from three independent adrenal glands. (B) Heatmap of the 15 most differentially expressed transcripts between basal and ACTH treatments. The ten most upregulated and five most downregulated genes are shown. Colors represent the expression level from the median of all the samples for each probe set. Results represent data from three experiments using cells isolated from three independent $F A$ glands. Full colour version of this figure available via http://dx.doi.org/10.1677/JME-10-0006. 
increased following treatment with ACTH for $48 \mathrm{~h}$. CYP17 showed the largest increase of 32-fold. This increase confirms that ACTH is a very potent steroidogenic activator that chronically increases the capacity of adrenal cells to produce steroid hormones by increasing steroidogenic enzyme expression. In addition, ACTH treatment increased the expression of its own receptor - MC2R (12-fold). Interestingly, an important component and effector of the MC2R system, the MRAP, was also upregulated by ACTH (16-fold).

\section{ACTH stimulates cortisol and DHEA-S production in FA}

Like AA cells, human FA cells are dependent on ACTH to increase steroidogenesis. To test the effects of ACTH on human FA, we isolated cells from three separate adrenals and ran three independent experiments. As shown in Fig. 3, both cortisol and DHEA-S levels were significantly stimulated by ACTH treatment, and these effects were time-dependent, continuing to magnify with time. By $48 \mathrm{~h}$, ACTH was able to increase DHEA-S by eightfold and cortisol by over 300 -fold when compared to basal steroid production. Six microarrays were performed on the 48-h ACTH treatment groups (Fig. 4A), and the genes that were most upregulated and downregulated are summarized in Fig. 4B and Table 2. Among the 18391 genes shown in the scatter plot, 84 of them were upregulated more than fourfold by 48-h ACTH treatment, and 5 genes were downregulated for more than fourfold. Four steroidogenic enzyme genes including HSD3B2, CYP21A2, CYP17A1, and $S T A R$ were represented in the list of ten genes most affected by ACTH. In this group, the mRNA encoding $H S D 3 B 2$ increased the most at 53 -fold above that seen in untreated cells.

\section{Common genes shared by AA and FA}

Comparing the pan-genomic effects of ACTH on AA and FA cells, we found a series of common genes that were increased in both cell types. When setting the threshold at a fourfold increase, there were 30 genes regulated by ACTH in AA, with 84 genes in FA (Fig. 5A). Among them, 20 genes were common, suggesting that those genes may represent a universal set of human adrenal ACTH targets and perform the critical functions associated with ACTH action. The heatmap for those 20 genes is shown in Fig. 5B, followed by the detailed fold changes in both cell types (Table 3 ). Among the 20 common genes, six were transcripts encoding steroidogenic enzymes/proteins, namely STAR, CYP11A1, CYP17A1, HSD3B2, CYP21A2, and CYP11B1. The ACTH receptor (MC2R) and MRAP were upregulated by ACTH in both cell cultures. There was also a significantly increased expression of the scavenger receptor type B class 1 (SCARB1) transcript with ACTH treatment. As the major HDL receptor in the adrenal gland, SCARB1 is shown to be regulated by cAMP and protein kinase C (PKC) pathways. Although

Table 2 Transcripts most regulated by ACTH treatment in fetal adrenal (FA) cells. Primary human FA cell cultures were treated with/without ACTH (10 nM) for $48 \mathrm{~h}$, and RNA was isolated for microarray analysis. Ten genes most upregulated and five genes most downregulated by ACTH treatment in human FA are shown. The gene symbol of each transcript is given in the first column, followed by the fold change between basal and ACTH treatments (mean fold change of three independent experiment \pm S.E.M.) and $P$ value. Result represents data from three experiments using cells isolated from three independent donor FA glands

Fold change

\pm S.E.M.
GenBank accession number

\section{Gene name}

\section{Gene}

symbol

$\begin{array}{lrll}\text { HSD3B2 } & 53.05 \pm 4.08 & 0.006 & \text { NM_000198.2 } \\ \text { CYP21A2 } & 52.00 \pm 4 \cdot 11 & 0.006 & \text { NM_000500.5 } \\ \text { GNRHR } & 23.60 \pm 0.67 & 0.001 & \text { NM_001012763.1 } \\ \text { AMDHD1 } & 19.92 \pm 1.04 & 0.003 & \text { NM_152435.1 } \\ \text { CD83 } & 14 \cdot 16 \pm 1.31 & 0.010 & \text { NM_004233.3 } \\ \text { TUBB4 } & 13.78 \pm 1.60 & 0.015 & \text { NM_006087.2 } \\ \text { CYP17A1 } & 13.22 \pm 1.48 & 0.014 & \text { NM_000102.3 } \\ \text { STAR } & 12.90 \pm 1.80 & 0.022 & \text { NM_001007243.1 } \\ \text { AQP2 } & 11.89 \pm 5.60 & 0.191 & \text { NM_000486.3 } \\ \text { GSTA1 } & 11.40 \pm 1.85 & 0.030 & \text { NM_145740.2 } \\ \text { SRD5A2L2 } & 0.11 \pm 0.02 & 0.0010 & \text { NM_001010874.3 } \\ \text { HOPX } & 0.15 \pm 0.01 & 0.0019 & \text { NM_032495.4 } \\ \text { HSPB7 } & 0.18 \pm 0.04 & 0.0002 & \text { NM_014424.3 } \\ \text { KCNS1 } & 0.23 \pm 0.02 & 0.0004 & \text { NM_002251.3 } \\ \text { ACTA1 } & 0.25 \pm 0.02 & 0.0010 & \text { NM_001100.3 }\end{array}$

\author{
$3 \beta$ hydroxysteroid dehydrogenase \\ Cytochrome P450, 21 hydroxylase \\ Gonadotropin-releasing hormone receptor \\ Amidohydrolase domain containing 1 \\ CD83 molecule \\ Homo sapiens tubulin, $\beta 4$ \\ Cytochrome P450, 17 $\alpha$ hydroxylase/17,20 lyase \\ Steroidogenic acute regulatory protein \\ Aquaporin 2 (collecting duct) \\ Glutathione S-transferase A1 \\ Steroid 5 alpha-reductase 2-like 2 \\ HOP homeobox \\ Heat shock 27 kDa protein family, member 7 (cardiovascular) \\ Potassium voltage-gated channel, delayed-rectifier, \\ subfamily $\mathrm{S}$, member 1 \\ Skeletal muscle $\alpha$-actin
}

$P$ value was calculated using paired $t$-test comparing the fold changes after ACTH treatment. 
A Genes upregulated by ACTH treatment by fourfold
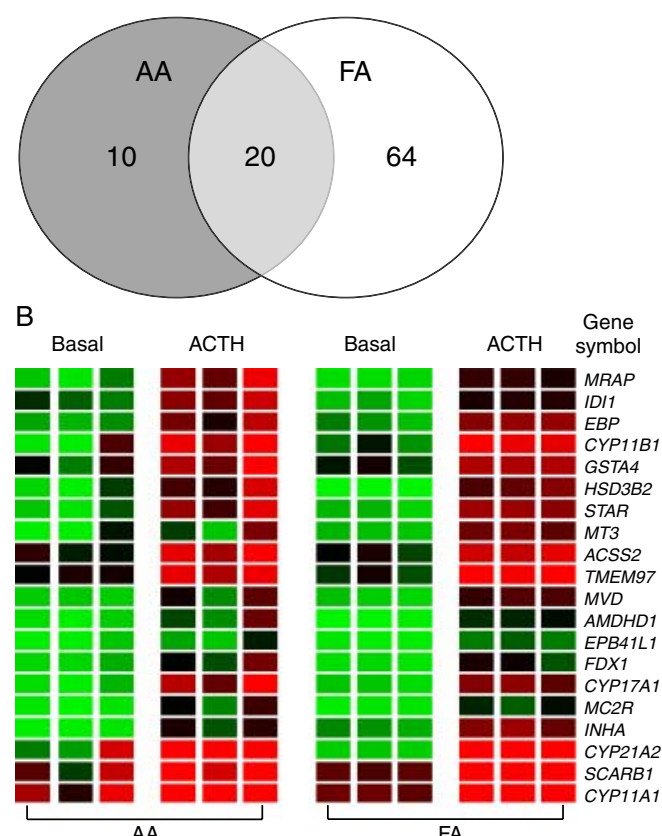

Fold change AA FA $16.20 \quad 8.54$ $\begin{array}{ll}5.76 & 4.77\end{array}$ $\begin{array}{rr}6.94 & 7.82 \\ 43.31 & 10.73\end{array}$ $\begin{array}{rr}43.31 & 10.73 \\ 4.87 & 4.27\end{array}$ $10.58 \quad 53.05$ $\begin{array}{ll}14.30 & 12.90\end{array}$ $\begin{array}{ll}6.72 & 8.04\end{array}$ $5.75 \quad 5.61$ $\begin{array}{ll}5.75 & 5.61 \\ 5 & \end{array}$ $\begin{array}{ll}5.43 & 8.68 \\ 5.81 & 7.57\end{array}$ $510 \quad 7.57$ $\begin{array}{rr}8.08 & 8.32\end{array}$ $6.04 \quad 7.65$ $31.64 \quad 13.22$ $12.42 \quad 11.01$ $14.75 \quad 6.15$ $20.64 \quad 52.00$ $5.55 \quad 683$ 0 100

Figure 5 Common genes that are increased by ACTH treatment in $A A$ and $F A$ cells. (A) Venn diagram of genes upregulated by ACTH by at least fourfold in AA and FA cells. Grey, AA cell; white, FA cell. (B) Heatmap of the 20 ACTH upregulated genes in both $A A$ and FA cells. Colors represent the expression level from the median of all the samples for each probe set. Results represent data from three experiments using cells isolated from three independent donor adrenal glands. Full colour version of this figure available via http://dx.doi.org/10.1677/JME-10-0006.

it is established that SCARB1-mediated selective uptake is not the major course of cholesterol supply in the human adrenal, this change of SCARB1 expression may suggest that HDL plays other important roles in adrenal function. Real-time qPCR was used to confirm microarray data for the eight genes that were most upregulated by ACTH and the one gene that was downregulated in both FA and AA cell types (Fig. 6). All nine genes examined by qPCR were regulated in a similar manner to that seen by microarray, thus confirming that they are ACTH-responsive genes in AA and FA cells.

\section{Discussion}

ACTH is the major regulator of adrenal steroidogenesis, and has been shown to increase aldosterone, cortisol, and DHEA production. Aside from steroidogenic enzymes, several other gene targets of ACTH have been identified. Schimmer et al. (2006) identified a series of ACTH-responsive genes using microarray analysis in the Y-1 mouse adrenal tumor cell model. However, there have been no studies about the global actions of ACTH on human adrenal cell gene expression. Herein, we used primary cultures of human adrenocortical cells as models and describe the genomic effects of ACTH.

The steroidogenic action of ACTH in the adrenal cortex has been well studied, and is believed to be mediated by cAMP and PKA via two temporal responses (Cote \& Yasumura 1975, Durand et al. 1987, Simpson et al. 1987, Sewer \& Waterman 2003). The acute response is mediated by the activity of the STAR protein, which leads to mobilization of cholesterol from cellular stores to the inner mitochondrial membrane where cholesterol side-chain cleavage (CYP11A1) is located (Fleury et al. 1996, 1998, Ariyoshi et al. 1998, Clark \& Combs 1999, Lehoux et al. 2003). Studies in fetal and AAs across several species have shown that the chronic response of ACTH includes the activation of genes encoding the steroidogenic enzymes, HSD3B2, CYP21, CYP17, and CYP11B1 (Di Blasio et al. 1990, Tangalakis et al. 1990, Neri et al. 1991, Mason et al. 1993, Lebrethon et al. 1994, Galtier et al. 1996, Coulter \& Jaffe 1998, Simmonds et al. 2001, Bassett et al. 2004, Ismat et al. 2005, Su et al. 2005, Carey et al. 2006, Schimmer et al. 2006, Banerjee et al. 2008, Fernandez-Ranvier et al. 2008). These gene targets were confirmed in the current study in AA and FA cells using microarray analysis. All the steroidogenic enzymes needed for cortisol synthesis were upregulated by ACTH treatment.

In agreement with previous studies (Mountjoy et al. 1994, Le Roy et al. 2000, Su et al. 2005, Carey et al. 2006, Johnston et al. 2007, Rehman et al. 2007), we found that the ACTH receptor MC2R was significantly stimulated by ACTH incubation (12-fold). We also noticed a significant increase in MRAP mRNA levels. As an essential component for MC2R function, MRAP was first identified by Metherell et al. (2004). Its mutation has been shown to be responsible for some cases of familial glucocorticoid deficiency type 2 , in which there is elevated ACTH, but circulating cortisol is low or absent (Metherell et al. 2005, Rumie et al. 2007). By stimulating expression of both MC2R and MRAP concomitantly, ACTH forms a feed forward loop leading to amplification of responsiveness.

As mentioned above, the only other microarray study regarding ACTH genomic effects on adrenal function was performed using the Y-1 mouse adrenal tumor cells (Schimmer et al. 2006). In this study, Y-1 adrenal cells were treated with ACTH $(20 \mathrm{nM})$ for $24 \mathrm{~h}$, and 588 genes were found to be significantly increased. Compared to their results, we also confirmed upregulation of steroidogenic enzymes, as well as two other transcripts, SCARB1 and INHA. When treating Y-1 
Table 3 Genes with increased expression in both human adult adrenal (AA) and fetal adrenal (FA) cells. The genes upregulated more than fourfold in AA and FA cells after 48-h ACTH treatment were compared, and common genes are listed below. The gene symbol and full name for each transcript are given in the first and last columns, followed by the fold change between basal and ACTH treatments and gene accession number

\begin{tabular}{|c|c|c|c|c|}
\hline \multirow[b]{2}{*}{$\begin{array}{l}\text { Gene } \\
\text { symbol }\end{array}$} & $\begin{array}{l}\text { Fold change } \\
\text { in HAA }\end{array}$ & $\begin{array}{l}\text { Fold change } \\
\text { in HFA }\end{array}$ & $\begin{array}{l}\text { GenBank accession } \\
\text { number }\end{array}$ & \multirow[t]{2}{*}{ Gene name } \\
\hline & & & & \\
\hline CYP11B1 & $43 \cdot 31$ & $10 \cdot 73$ & NM_001026213.1 & Cytochrome $\mathrm{P} 450,11 \beta$ hydroxylase \\
\hline CYP17A1 & 31.64 & $13 \cdot 22$ & NM_000102.3 & Cytochrome $\mathrm{P} 450,17 \alpha$ hydroxylase $/ 17,20$ lyase \\
\hline CYP21A2 & $20 \cdot 64$ & $52 \cdot 00$ & NM_000500.5 & Cytochrome P450, 21 hydroxylase \\
\hline STAR & $14 \cdot 30$ & $12 \cdot 90$ & NM_001007243.1 & Steroidogenic acute regulatory protein \\
\hline MC2R & $12 \cdot 42$ & $11 \cdot 01$ & NM_000529.2 & Melanocortin 2 receptor \\
\hline HSD3B2 & $10 \cdot 58$ & 53.05 & NM_000198.2 & $3 \beta$ hydroxysteroid dehydrogenase \\
\hline$A M D H D 1$ & $8 \cdot 19$ & $19 \cdot 92$ & NM_152435.1 & Amidohydrolase domain containing 1 \\
\hline$E B P$ & 6.94 & $7 \cdot 82$ & NM_006579.1 & Emopamil binding protein (sterol isomerase) \\
\hline MT3 & $6 \cdot 72$ & 8.04 & NM_005954.2 & Metallothionein 3 \\
\hline CYP11A1 & $5 \cdot 55$ & 6.83 & NM_000781.2 & Cytochrome P450, side-chain cleavage \\
\hline TMEM97 & $5 \cdot 43$ & 8.68 & NM_014573.2 & Transmembrane protein 97 \\
\hline GSTA4 & $4 \cdot 87$ & $4 \cdot 27$ & NM_001512.2 & Glutathione $S$-transferase, A4 \\
\hline EPB41L1 & $4 \cdot 08$ & $8 \cdot 32$ & NM_177996.1 & Erythrocyte membrane protein band 4.1-like 1 \\
\hline
\end{tabular}

mouse adrenal cells with ACTH, Schimmer et al. (2006) was able to detect a fourfold change in SCARB1 transcript, suggesting this multifunction HDL receptor is a common ACTH target shared between humans and mice. INHA was also stimulated in FA cells and shown to increase in Y-1 cells (Schimmer et al. 2006). Although normally associated with gonadal function, INHA has been shown to influence adrenal activity. INHA expression appears to correlate with CYP17 expression in human and rat adrenocortical tissues (Wang et al. 2003, Hofland et al. 2006), and can antagonize the inhibitory effects of activin and bone morphogenetic protein on Cyp17 mRNA in a mouse adrenocortical cell line (Farnworth et al. 2006).

In addition to the genes previously mentioned, $R D H 12$ was also among the top genes upregulated by ACTH in AA cells. RDH12 is an efficient NADPH-dependent retinal reductase, displaying high activity toward 9-cis- and all-trans-retinol (Haeseleer et al. 2002, Janecke et al. 2004, Maeda et al. 2006). RDH12 overexpression in HEK293 cells was able to convert dihydrotestosterone to androstanediol (Keller \& Adamski 2007); however, its ability to produce androgens has not been validated in adrenocortical cells. The functions of these candidates in ACTH regulation of the adrenal gland need further elucidation.

Of all the genes upregulated in human FA, one interesting finding is the GNRHR gene. In the previous study, we demonstrated that GNRHR is the most differentially expressed G-protein-coupled receptor between AA and FA (Xing et al. 2009). In the current study, GNRHR transcript was also greatly stimulated in FA after ACTH treatment, suggesting its regulation by the ACTH, cAMP, and PKA pathways. The role of GNRHR in the human FA, however, remains to be determined.

The comparison of AA and FA microarray data gave 20 common genes that were upregulated by ACTH in both cell models. Comparison of these unique models provided a series of broad ACTH target genes. Other published targets of ACTH in adrenal glands include a series of transcription factors (Sewer \& Waterman 2003), bTREK-1 potassium channel (Liu et al. 2008), and genes involved in cell proliferation (Lotfi et al. 2000, Rocha et al. 2003). However, due to the chronic treatment period $(48 \mathrm{~h})$ used in the current study, we were not able to detect increases of these rapid response genes in our microarray analysis results.

Among genes that ACTH decreased expression by greater than fourfold, $H O P X$ is the only one seen in both AA and FA cells. HOPX was first identified in lung cancer as a potential tumor repressor gene (Chen et al. 2003, 2007). Recently, HOPX was shown to be involved in cardiac development (Chen et al. 2002, Ismat et al. 2005), and function by physically interacting with serum response factor (SRF) and the inhibition of 

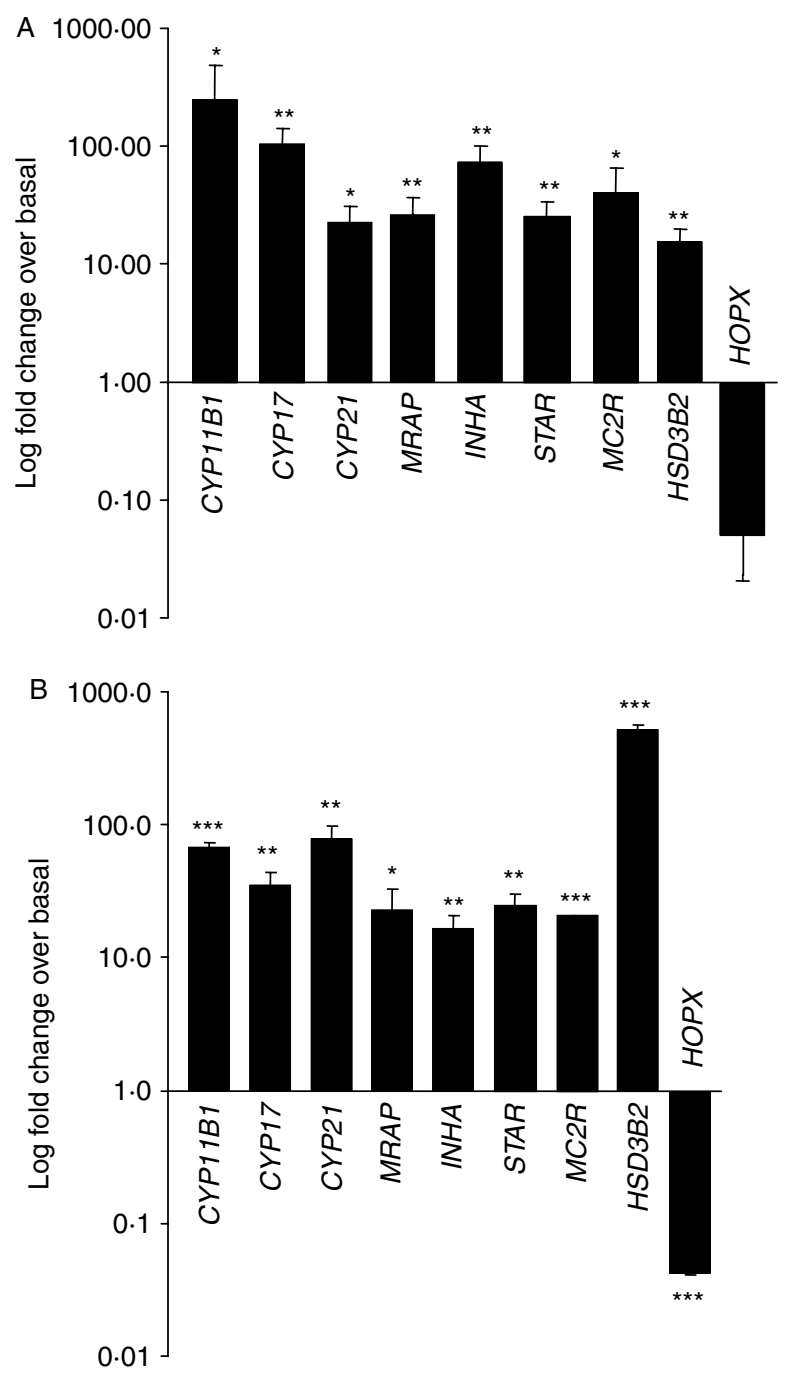

Figure 6 Analysis of common ACTH-responsive gene expression in $A A$ and $F A$ cells using qPCR. Primary $A A(A)$ and $F A(B)$ cells were incubated with or without ACTH for $48 \mathrm{~h}$. Transcript levels of the eight most upregulated and one downregulated genes, selected from those found in Table 3 and Fig. 5, were quantified using qPCR. Data were normalized to $18 \mathrm{~S}$ rRNA and expressed as fold change over the basal treatment. Results represent data from three experiments using cells isolated from three independent adrenal glands. Statistics were calculated using paired Student's $t$-test, comparing the normalized $C_{\mathrm{t}}$ values of basal versus ACTH treatment. ${ }^{\star} P<0.05 ;{ }^{\star \star} P<0.01 ;{ }^{* \star} P<0.001$.

SRF-dependent transcription (Yamaguchi et al. 2009). Although no studies have examined HOPX function in the adrenal gland, its tumor repressor activity and the downregulation by ACTH treatment suggest that it may be relevant to adrenal proliferation.

The WNT1-inducible signaling pathway protein 2 (WISP2) was also significantly downregulated after ACTH treatment in AA cells. WISP2 is a member of the connective tissue growth factor/cysteine-rich $61 /$ nephroblastoma overexpressed family, and is a potential target for WNT1 regulation in the mouse model (Pennica et al. 1998). Increased expression of WISP is detected in human colon cancer and several breast cancer cell lines (Pennica et al. 1998, Dhar et al. 2007, 2008, Banerjee et al. 2008). Studies by Stratakis et al. have suggested the involvement of this gene in adrenal disease, specifically primary pigmented nodular adrenocortical disease (Bourdeau et al. 2004, Horvath et al. 2006, Iliopoulos et al. 2009). However, in our system, we found that the PKA pathway represses the expression of WISP2 gene. The other ACTHrepressed gene in AA cells was HTR2B. Initially characterized in isolated rat stomach fundus (Clineschmidt et al. 1985, Komada \& Yano 2007), HTR2B is a widely expressed G-protein-coupled receptor, functioning through PKC-dependent ERK phosphorylation (Cox \& Cohen 1995, 1996, Li et al. 2008, Wouters et al. 2009). A study comparing benign adrenocortical tumors and adrenocortical carcinoma identified HTR2B as a potential diagnosis biomarker for distinguishing benign from malignant adrenocortical tumors (Fernandez-Ranvier et al. 2008). This suggested that HTR2B may be involved in adrenal cell growth regulation.

In summary, by applying a microarray approach, we defined the genomic effects of ACTH in human adult and FA primary cultures. The newly defined adrenal ACTH-responsive genes can provide clues to the mechanism of ACTH-regulated steroidogenesis and cell growth, and may lead to further understanding of the global functions of ACTH in the adrenal gland. This knowledge may be helpful in solving and developing treatments for adrenal diseases including hyperplasia and tumors.

\section{Declaration of interest}

The authors declare that there is no conflict of interest that could be perceived as prejudicing the impartiality of the research reported.

\section{Funding}

This work was supported by National Institute of Health grant DK069950 and DK43140 to W E Rainey, HD11149 to W E Rainey and C R Parker, and an MCG Diabetes and Obesity Discovery Institute pilot grant to M Edwards.

\section{Acknowledgements}

We would like to thank Medical College of Georgia, Adrenal Center, for helping to collect adrenal samples and Mr Ashok Shama for his help in statistical analysis of the data. Data deposition: microarray data have been deposited in the NCBI/GEO database under the accession number GSE20676. 


\section{References}

Ariyoshi N, Kim YC, Artemenko I, Bhattacharyya KK \& Jefcoate CR 1998 Characterization of the rat Star gene that encodes the predominant 3.5-kilobase pair mRNA. ACTH stimulation of adrenal steroids in vivo precedes elevation of Star mRNA and protein. Journal of Biological Chemistry 273 7610-7619.

Banerjee S, Dhar G, Haque I, Kambhampati S, Mehta S, Sengupta K, Tawfik O, Phillips TA \& Banerjee SK 2008 CCN5/WISP-2 expression in breast adenocarcinoma is associated with less frequent progression of the disease and suppresses the invasive phenotypes of tumor cells. Cancer Research 68 7606-7612.

Bassett MH, Suzuki T, Sasano H, De Vries CJ, Jimenez PT, Carr BR \& Rainey WE 2004 The orphan nuclear receptor NGFIB regulates transcription of $3 \beta$-hydroxysteroid dehydrogenase. Implications for the control of adrenal functional zonation. Journal of Biological Chemistry 279 37622-37630.

Bourdeau I, Antonini SR, Lacroix A, Kirschner LS, Matyakhina L, Lorang D, Libutti SK \& Stratakis CA 2004 Gene array analysis of macronodular adrenal hyperplasia confirms clinical heterogeneity and identifies several candidate genes as molecular mediators. Oncogene 23 1575-1585.

Carey LC, Su Y, Valego NK \& Rose JC 2006 Infusion of ACTH stimulates expression of adrenal ACTH receptor and steroidogenic acute regulatory protein mRNA in fetal sheep. American Journal of Physiology. Endocrinology and Metabolism 291 E214-E220.

Cecim M, Alvarez-Sanz M, Van de Kar L, Milton S \& Bartke A 1996 Increased plasma corticosterone levels in bovine growth hormone (bGH) transgenic mice: effects of ACTH, GH and IGF-I on in vitro adrenal corticosterone production. Transgenic Research 5 187-192.

Chen F, Kook H, Milewski R, Gitler AD, Lu MM, Li J, Nazarian R, Schnepp R, Jen K, Biben C et al. 2002 Hop is an unusual homeobox gene that modulates cardiac development. Cell 110 713-723.

Chen Y, Petersen S, Pacyna-Gengelbach M, Pietas A \& Petersen I 2003 Identification of a novel homeobox-containing gene, LAGY, which is downregulated in lung cancer. Oncology 64 450-458.

Chen Y, Pacyna-Gengelbach M, Deutschmann N, Niesporek S \& Petersen I 2007 Homeobox gene HOP has a potential tumor suppressive activity in human lung cancer. International Journal of Cancer 121 1021-1027.

Clark BJ \& Combs R 1999 Angiotensin II and cyclic adenosine $3^{\prime}, 5^{\prime}$ monophosphate induce human steroidogenic acute regulatory protein transcription through a common steroidogenic factor-1 element. Endocrinology 140 4390-4398.

Clineschmidt BV, Reiss DR, Pettibone DJ \& Robinson JL 1985 Characterization of 5-hydroxytryptamine receptors in rat stomach fundus. Journal of Pharmacology and Experimental Therapeutics 235 696-708.

Cote TE \& Yasumura S 1975 Effect of ACTH and histamine stress on serum corticosterone and adrenal cyclic AMP levels in immature rats. Endocrinology 96 1044-1047.

Coulter CL \& Jaffe RB 1998 Functional maturation of the primate fetal adrenal in vivo. 3. Specific zonal localization and developmental regulation of CYP21A2 (P450c21) and CYP11B1/CYP11B2 (P450c11/aldosterone synthase) lead to integrated concept of zonal and temporal steroid biosynthesis. Endocrinology 139 $5144-5150$.

Cox DA \& Cohen ML 1995 5-Hydroxytryptamine2B receptor signaling in rat stomach fundus: role of voltage-dependent calcium channels, intracellular calcium release and protein kinase C. Journal of Pharmacology and Experimental Therapeutics 272 143-150.

Cox DA \& Cohen ML 1996 5-HT2B receptor signaling in the rat stomach fundus: dependence on calcium influx, calcium release and protein kinase C. Behavioural Brain Research 73 289-292.

Dhar K, Banerjee S, Dhar G, Sengupta K \& Banerjee SK 2007 Insulinlike growth factor-1 (IGF-1) induces WISP-2/CCN5 via multiple molecular cross-talks and is essential for mitogenic switch by IGF-1 axis in estrogen receptor-positive breast tumor cells. Cancer Research 67 1520-1526.
Dhar G, Banerjee S, Dhar K, Tawfik O, Mayo MS, Vanveldhuizen PJ \& Banerjee SK 2008 Gain of oncogenic function of p53 mutants induces invasive phenotypes in human breast cancer cells by silencing CCN5/WISP-2. Cancer Research 68 4580-4587.

Di Blasio AM, Fujii DK, Yamamoto M, Martin MC \& Jaffe RB 1990 Maintenance of cell proliferation and steroidogenesis in cultured human fetal adrenal cells chronically exposed to adrenocorticotropic hormone: rationalization of in vitro and in vivo findings. Biology of Reproduction 42 683-691.

Durand P, Cathiard AM, Naaman E \& Saez JM 1987 Adrenal adenylate cyclase and steroidogenic activities of 63 day old ovine fetuses: in vitro effects of ACTH1-24 and forskolin. Biochimie 69 629-638.

Farnworth PG, Stanton PG, Wang Y, Escalona R, Findlay JK \& Ooi GT 2006 Inhibins differentially antagonize activin and bone morphogenetic protein action in a mouse adrenocortical cell line. Endocrinology 147 3462-3471.

Fernandez-Ranvier GG, Weng J, Yeh RF, Khanafshar E, Suh I, Barker C, Duh QY, Clark OH \& Kebebew E 2008 Identification of biomarkers of adrenocortical carcinoma using genomewide gene expression profiling. Archives of Surgery 143 841-846 (discussion 846).

Fleury A, Cloutier M, Ducharme L, Lefebvre A, LeHoux J \& LeHoux JG 1996 Adrenocorticotropin regulates the level of the steroidogenic acute regulatory (StAR) protein mRNA in hamster adrenals. Endocrine Research 22 515-520.

Fleury A, Ducharme L \& LeHoux JG 1998 In vivo effects of adrenocorticotrophin on the expression of the hamster steroidogenic acute regulatory protein. Journal of Molecular Endocrinology 21 131-139.

Gaillard I, Keramidas M, Liakos P, Vilgrain I, Feige JJ \& Vittet D 2000 ACTH-regulated expression of vascular endothelial growth factor in the adult bovine adrenal cortex: a possible role in the maintenance of the microvasculature. Journal of Cellular Physiology 185 226-234.

Galtier A, Liakos P, Keramidas M, Feige JJ, Chambaz EM \& Defaye G 1996 ACTH angiotensin II and TGF beta participate in the regulation of steroidogenesis in bovine adrenal glomerulosa cells. Endocrine Research 22 607-612.

Haeseleer F, Jang GF, Imanishi Y, Driessen CA, Matsumura M, Nelson PS \& Palczewski K 2002 Dual-substrate specificity short chain retinol dehydrogenases from the vertebrate retina. Journal of Biological Chemistry 277 45537-45546.

Hofland J, Timmerman MA, de Herder WW, van Schaik RH, de Krijger RR \& de Jong FH 2006 Expression of activin and inhibin subunits, receptors and binding proteins in human adrenocortical neoplasms. Clinical Endocrinology 65 792-799.

Horvath A, Mathyakina L, Vong Q, Baxendale V, Pang AL, Chan WY \& Stratakis CA 2006 Serial analysis of gene expression in adrenocortical hyperplasia caused by a germline PRKAR1A mutation. Journal of Clinical Endocrinology and Metabolism 91 584-596.

Iliopoulos D, Bimpaki EI, Nesterova M \& Stratakis CA 2009 MicroRNA signature of primary pigmented nodular adrenocortical disease: clinical correlations and regulation of Wnt signaling. Cancer Research 69 3278-3282.

Ismat FA, Zhang M, Kook H, Huang B, Zhou R, Ferrari VA, Epstein JA \& Patel VV 2005 Homeobox protein Hop functions in the adult cardiac conduction system. Circulation Research 96 898-903.

Janecke AR, Thompson DA, Utermann G, Becker C, Hubner CA, Schmid E, McHenry CL, Nair AR, Ruschendorf F, Heckenlively J et al. 2004 Mutations in RDH12 encoding a photoreceptor cell retinol dehydrogenase cause childhood-onset severe retinal dystrophy. Nature Genetics 36 850-854.

Johnston H, King PJ \& O'Shaughnessy PJ 2007 Effects of ACTH and expression of the melanocortin-2 receptor in the neonatal mouse testis. Reproduction 133 1181-1187.

Keller B \& Adamski J 2007 RDH12, a retinol dehydrogenase causing Leber's congenital amaurosis, is also involved in steroid metabolism. Journal of Steroid Biochemistry and Molecular Biology 104 $190-194$. 
Komada T \& Yano S 2007 Pharmacological characterization of 5-hydroxytryptamine-receptor subtypes in circular muscle from the rat stomach. Biological \& Pharmaceutical Bulletin 30 508-513.

Lebrethon MC, Jaillard C, Naville D, Begeot M \& Saez JM 1994 Regulation of corticotropin and steroidogenic enzyme mRNAs in human fetal adrenal cells by corticotropin, angiotensin-II and transforming growth factor $\beta 1$. Molecular and Cellular Endocrinology 106 137-143.

Lehoux JG, Mathieu A, Lavigne P \& Fleury A 2003 Adrenocorticotropin regulation of steroidogenic acute regulatory protein. Microscopic Research and Technique 61 288-299.

Le Roy C, Li JY, Stocco DM, Langlois D \& Saez JM 2000 Regulation by adrenocorticotropin (ACTH), angiotensin II, transforming growth factor- $\beta$, and insulin-like growth factor I of bovine adrenal cell steroidogenic capacity and expression of ACTH receptor, steroidogenic acute regulatory protein, cytochrome P450c17, and 3ß-hydroxysteroid dehydrogenase. Endocrinology 141 1599-1607.

Li B, Zhang S, Zhang H, Nu W, Cai L, Hertz L \& Peng L 2008 Fluoxetine-mediated 5-HT2B receptor stimulation in astrocytes causes EGF receptor transactivation and ERK phosphorylation. Psychopharmacology 201 443-458.

Liu H, Enyeart JA \& Enyeart JJ 2008 ACTH inhibits bTREK-1 K+ channels through multiple cAMP-dependent signaling pathways. Journal of General Physiology 132 279-294.

Lotfi CF, Lepique AP, Forti FL, Schwindt TT, Eichler CB, Santos MO, Rebustini IT, Hajj GN, Juliano L \& Armelin HA 2000 Proliferative signaling initiated in ACTH receptors. Brazilian Journal of Medical and Biological Research 33 1133-1140.

Maeda A, Maeda T, Imanishi Y, Sun W, Jastrzebska B, Hatala DA, Winkens HJ, Hofmann KP, Janssen JJ, Baehr W et al. 2006 Retinol dehydrogenase (RDH12) protects photoreceptors from lightinduced degeneration in mice. Journal of Biological Chemistry 281 37697-37704.

Markowska A, Rebuffat P, Rocco S, Gottardo G, Mazzocchi G \& Nussdorfer GG 1993 Evidence that an extrahypothalamic pituitary corticotropin-releasing hormone $(\mathrm{CRH}) /$ adrenocorticotropin (ACTH) system controls adrenal growth and secretion in rats. Cell and Tissue Research 272 439-445.

Mason JI, Ushijima K, Doody KM, Nagai K, Naville D, Head JR, Milewich L, Rainey WE \& Ralph MM 1993 Regulation of expression

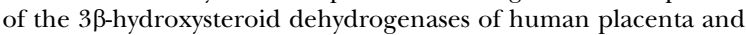
fetal adrenal. Journal of Steroid Biochemistry and Molecular Biology 47 $151-159$.

Metherell LA, Cooray S, Huebner A, Ruschendorf F, Naville D, Begeot M \& Clark AJ 2004 Mutations in a novel gene, encoding a single transmembrane domain protein are associated with familial glucocorticoid deficiency type 2. Endocrine Research 30 889-890.

Metherell LA, Chapple JP, Cooray S, David A, Becker C, Ruschendorf F, Naville D, Begeot M, Khoo B, Nurnberg P et al. 2005 Mutations in MRAP, encoding a new interacting partner of the ACTH receptor, cause familial glucocorticoid deficiency type 2. Nature Genetics 37 166-170.

Mountjoy KG, Bird IM, Rainey WE \& Cone RD 1994 ACTH induces up-regulation of ACTH receptor mRNA in mouse and human adrenocortical cell lines. Molecular and Cellular Endocrinology 99 R17-R20.

Neri G, Andreis PG \& Nussdorfer GG 1991 Comparison of ACTH and corticotropin-releasing hormone effects on rat adrenal steroidogenesis in vitro. Research in Experimental Medicine 191 291-295.

Pennica D, Swanson TA, Welsh JW, Roy MA, Lawrence DA, Lee J, Brush J, Taneyhill LA, Deuel B, Lew M et al. 1998 WISP genes are members of the connective tissue growth factor family that are up-regulated in wnt-1-transformed cells and aberrantly expressed in human colon tumors. PNAS 95 14717-14722.
Pezzi V, Mathis JM, Rainey WE \& Carr BR 2003 Profiling transcript levels for steroidogenic enzymes in fetal tissues. Journal of Steroid Biochemistry and Molecular Biology 87 181-189.

Rehman KS, Sirianni R, Parker CR Jr, Rainey WE \& Carr BR 2007 The regulation of adrenocorticotrophic hormone receptor by corticotropin-releasing hormone in human fetal adrenal definitive/transitional zone cells. Reproductive Sciences 14 578-587.

Rocha KM, Forti FL, Lepique AP \& Armelin HA 2003 Deconstructing the molecular mechanisms of cell cycle control in a mouse adrenocortical cell line: roles of ACTH. Microscopic Research and Technique 61 268-274.

Rumie H, Metherell LA, Clark AJ, Beauloye V \& Maes M 2007 Clinical and biological phenotype of a patient with familial glucocorticoid deficiency type 2 caused by a mutation of melanocortin 2 receptor accessory protein. European Journal of Endocrinology 157 539-542.

Schimmer BP, Cordova M, Cheng H, Tsao A, Goryachev AB, Schimmer AD \& Morris Q 2006 Global profiles of gene expression induced by adrenocorticotropin in Y1 mouse adrenal cells. Endocrinology 147 2357-2367.

Sewer MB \& Waterman MR 2003 ACTH modulation of transcription factors responsible for steroid hydroxylase gene expression in the adrenal cortex. Microscopic Research and Technique 61 300-307.

Simmonds PJ, Phillips ID, Poore KR, Coghill ID, Young IR \& Canny BJ 2001 The role of the pituitary gland and ACTH in the regulation of mRNAs encoding proteins essential for adrenal steroidogenesis in the late-gestation ovine fetus. Journal of Endocrinology 168 475-485.

Simpson ER, Mason JI, John ME, Zuber MX, Rodgers RJ \& Waterman MR 1987 Regulation of the biosynthesis of steroidogenic enzymes. Journal of Steroid Biochemistry 27 801-805.

Su Y, Carey LC, Valego NK \& Rose JC 2005 Developmental changes in adrenocorticotrophin (ACTH)-induced expression of ACTH receptor and steroid acute regulatory protein mRNA in ovine fetal adrenal cells. Journal of the Society for Gynecologic Investigation 12 416-420.

Tangalakis K, Coghlan JP, Crawford R, Hammond VE \& Wintour EM 1990 Steroid hydroxylase gene expression in the ovine fetal adrenal gland following ACTH infusion. Acta Endocrinologica 123 371-377.

Wang EY, Ma EY \& Woodruff TK 2003 Activin signal transduction in the fetal rat adrenal gland and in human H295R cells. Journal of Endocrinology 178 137-148.

Wouters MM, Roeder JL, Tharayil VS, Stanich JE, Strege PR, Lei S, Bardsley MR, Ordog T, Gibbons SJ \& Farrugia G 2009 Protein kinase $\mathrm{C} \gamma$ mediates regulation of proliferation by the serotonin 5-hydroxytryptamine receptor 2B. Journal of Biological Chemistry 284 21177-21184.

Xing Y, Nakamura Y \& Rainey WE 2009 G protein-coupled receptor expression in the adult and fetal adrenal glands. Molecular and Cellular Endocrinology 300 43-50.

Yamaguchi S, Asanoma K, Takao T, Kato K \& Wake N 2009 Homeobox gene HOPX is epigenetically silenced in human uterine endometrial cancer and suppresses estrogen-stimulated proliferation of cancer cells by inhibiting serum response factor. International Journal of Cancer 124 2577-2588.

Ye P, Mariniello B, Mantero F, Shibata H \& Rainey WE 2007 G-proteincoupled receptors in aldosterone-producing adenomas: a potential cause of hyperaldosteronism. Journal of Endocrinology 195 39-48.

Received in final form 21 April 2010

Accepted 10 May 2010

Made available online as an Accepted Preprint 11 May 2010 